\title{
Polyfunctional modifier for bio-corrosion resistant high-performance fine-aggregate concretes
}

\author{
Valentina Anatolyevna Poluektova \\ Department of pure and applied chemistry \\ Belgorod State Technological University named after \\ V.G. Shukhov \\ BSTU named after V.G. Shoukhov \\ Belgorod, Russia \\ 308012, Belgorod, Kostukov St, 46 \\ v.a.poluektova@gmail.com
}

\author{
Valentina Dmitryevna Mukhacheva \\ Department of pure and applied chemistry \\ Belgorod State Technological University named after \\ V.G. Shukhov \\ BSTU named after V.G. Shoukhov \\ Belgorod, Russia \\ 308012, Belgorod, Kostukov St, 46 \\ mukhachevavd@mail.ru
}

\author{
Julia Vladimirovna Denisova \\ Department of architectural constructions \\ Belgorod State Technological University named after V.G. Shukhov \\ BSTU named after V.G. Shoukhov \\ Belgorod, Russia \\ 308012, Belgorod, Kostukov St, 46 \\ jdenisowa@mail.ru
}

\begin{abstract}
Use of binders with low water demand opens prospects for obtaining high-performance concretes. A polyfunctional modifier based on resol-type resorcinol-furfural oligomers allows one to obtain binders with low water demand and high specific surface area, compressive strength, and waterreducing ability. This research demonstrates that a more intensive strength development for 1-2 days of curing is observed in concretes based on low water demand binders compared to the reference sample. During this process, a denser microcrystalline structure with no large-grained formations or visible defects is formed. It was proved that introduction of the optimum quantity of the modifier into a binder completely suppresses mold growth. Isolates of Aspergillus niger and Penicillium chrisogenum Thom fungi were used as the biological deterioration factor for specimen. Assessment of antifungal properties of resorcinolfurfural oligomers on a six-point scale (sample/environment) is presented. Strength properties of the concrete with the modifier in question are significantly increased due to the decrease of the water-cement ratio, the reduction of microfractures within the concrete, higher density of its structure, and absence of biocorrosion. The resorcinol-furfural polyfunctional modifier can be used to produce innovative high-strength materials for use in additive manufacturing and further use of the produced articles in biologically active environments.
\end{abstract}

Keywords - high-performance concrete; low water demand binder; water-reducing ability; antifungal properties; biocorrosion.

\section{INTRODUCTION}

High-performance concretes are materials of the XXI century, highly demanded by both builders and designers, including specialists in innovative materials and articles produced by $3 \mathrm{D}$ printing.

Architectural objects and construction sites are operated under the active influence of temperature, humidity, chemicals, and microorganisms of the environment. The combination of favorable acidity and high humidity leads to colonization of the surface of construction materials by microorganisms and their further microzonal penetration inside the material, which leads to its premature deterioration $[1,2]$.

One of the ways to increase the quality of concrete products is the use of efficient organic polymer additives, modifiers of surfaces of concrete mix phase interfaces. New prospects for obtaining high-performance concretes are seen in the use of low water demand binders (LWRB), obtained by intergrinding Portland cement clinker with mineral additives and modifiers [3]. Today's visions of the outcomes of using LWRBs to obtain concretes are sketchy and not always conclusive [4-6]. On the one hand, use of modifiers and LWRBs leads to obtaining a highly homogeneous structure of cement rock with high density due to the low water-cement (W/C) ratio [7-8], which makes products durable and longlasting. On the other hand, some specialists believe that the low W/C ratio negatively affects the longevity of concrete and its strength [9]. Existence of different opinions requires further study of use of LWRBs in high-performance concrete production.

Another way of increasing the quality and further advancing the technology of producing building products and materials from concrete is conditioned by the need for reliable bio-corrosion resistant materials. Damage from bio-corrosion 
reaches billions of dollars per year and keeps rising with the increase in stocks of materials and products. Possessing a unique fermentation mechanism, fungi are able to deteriorate virtually all materials that their spores deposit on by turning them into simple mineral compounds. Only the presence of enzyme poisons in the substance can interrupt the damaging effect of the fungi. Microorganisms in the inactive state are always present on the samples' surfaces.

One of the most widespread methods of protecting materials from biodeterioration is the use of chemical compounds with biocidal effect, the so-called antifungal additives. Fungicides are applied to the surface of the material or included in its composition on the stage of its production [1, 2].

However, use of antifungal additives is substantially restricted. Many of the currently used fungicides that are added into a material's composition impair its physical and mechanical properties. This gives increased importance to the search of efficient polyfunctional additives that would intensify the process of curing and significantly increase the strength properties of building materials during use in harsh ecological conditions.

This paper studies the specifics of use of resol-type resorcinol-furfural oligomers as a modifier in obtaining LWRBs and provides assessment of bio-corrosion resistance properties of LWRB-based fine-aggregate concretes with the purpose of their use in additive technologies.

\section{METHOD}

The object of research are samples of fine-aggregate concrete based on a low water requirement binder.

Production of the LRWB included clinker by the Belgorod cement plant (Belgorodskiy Cement, affiliate of Eurocement Group), granulated blast-furnace slag by Novolipetsk Steel, gypsum containing at least $92.5 \%$ of calcium sulfate dihydrate and $46.3 \%$ of $\mathrm{SO}_{3}$, which meets the GOST 4013-90 requirements, and a synthesized modifier based on resorcinolfurfural resols.

Resorcinol-furfural oligomers were synthesized in alkaline environment at a temperature of $70^{\circ} \mathrm{C}$ in a three-necked flask equipped with a stirrer, thermometer, and a reflux condenser. The obtained $20 \%$ solution was subjected to vacuum drying.

The following materials were used during the preparation of the cement-sand samples: PTs-500-D0 cement by Belgorod cement plant with the specific surface area (SSA) of 354 $\mathrm{m} 2 / \mathrm{kg}$ and the low water requirement binder VNV-50 with the SSA of $475 \mathrm{~m} 2 / \mathrm{kg}$, sand from the Belgorod quarry with the fineness modulus of $1.2,2.3 \%$ moisture, and the density of $2600 \mathrm{~kg} / \mathrm{m} 3$.

Isolates of Aspergillus niger and Penicillium chrisogenum Thom fungi were used as the biological deterioration factor.
Fungal resistance was determined according to GOST 9.048-89, method B, which identifies the availability of antifungal properties in a material. The minimum duration of tests to determine antifungal properties is 14 days (28 days in the case of this research). The results were processed to identify the samples' antifungal properties according to the degree of mold growth on a six-point scale: a material passed the test if the fungi on its surface had the development intensity of no more than three points.

The antifungal properties of the modifier under study were assessed by inoculating the isolates on the surface of solid and liquid growth media (Czapek-Dox medium), into which different concentrations of fungicide were introduced. The reference were media without fungicide. The modifier's antifungal effect was determined visually according to fungus growth on the surface, grading it on a six-point scale as prescribed in GOST 9.048-89.

0 points - no spores or conidia detected microscopically;

1 point - germinated spores and insignificantly developed mycelium is seen microscopically;

2 points - developed mycelium is seen microscopically, possible sporulation;

3 points - mycelium and sporulation are barely visible with the unaided eye, but are clearly seen microscopically;

4 points - the development of fungi covering less than $25 \%$ of the studied surface are clearly visible with the unaided eye;

5 points - the development of fungi covering more than $25 \%$ of the studied surface are clearly visible with the unaided eye;

Morphological and cultural properties of Aspergillus niger and Penicillium chrisogenum test organisms were studied in agar and liquid growth medium, into which different concentrations of fungicide were introduced. As the isolates grew, differences in colony morphology, mycelium color, and sporulation start time were visually observed. A medium with isolates without fungicide served as a reference.

The effect of the modifier on the properties of mortar mixes and fine-grained concretes was studied using comprehensive research methods regulated by their respective standards.

Microstructures of the samples were studied using images produced by MIRA3 TESCAN electron microscope.

\section{MAIN PART}

\section{A. Preparation of resorcinol-furfural modifier}

The pattern of obtaining the resorcinol-furfural modifier can be represented as follows: 
<smiles>[CH+]c1cccc([O-])c1</smiles><smiles>Cc1c([O-])ccc(C(C)c2ccco2)c1[O-]</smiles>

According to the standard GOST 24211-2008 [10], the synthesized additive based on resorcinol-furfural resols can be classified as a superplasticizer. Its plasticizing effect is on par with its popularly known counterparts from around the world $[11,12]$.

\section{B. Preparation of low water requirement binder and study of its properties}

The LWRB was obtained through intergrinding the clinker, mineral additives and the modifier in a twocompartment laboratory mill with the maximum load of eight $\mathrm{kg}$. The clinker was previously comminuted using a laboratory jaw crusher. The properties of the resulting LWRB-50 binder (the number reflects clinker content) are shown in Table I.

The research showed that increasing the concentration of the additive can result in obtaining a LWRB with a higher specific surface area and compressive strength.

TABLE I. PROPERTIES OF THE LWRB-50 LOW WATER REQUIREMENT BINDER

\begin{tabular}{|c|c|c|c|}
\hline $\begin{array}{c}\text { Modifier } \\
\text { concentration, } \\
\%\end{array}$ & SSA, $\mathbf{~ m}^{\mathbf{2}} \mathbf{k g}$ & $\begin{array}{c}\text { Normal } \\
\text { consisten } \\
\text { cy, \% }\end{array}$ & $\begin{array}{c}\text { Compressive } \\
\text { strength, MPa } \\
\text { (28 days) }\end{array}$ \\
\hline 0.4 & 468 & 24.2 & 79.2 \\
\hline 0.45 & 475 & 22.0 & 86.5 \\
\hline 0.5 & 492 & 21.3 & 69.3 \\
\hline
\end{tabular}

The LWRB-50 obtained after introducing the optimal content of the resorcinol-furfural modifier $(0,45 \%)$ was used to obtain fine-aggregate concretes, whose properties are presented in Table II. The results are given in comparison with concrete based on the common Portland cement both without the modifier, was well as with it, introduced together with gauging water.

TABLE II. PROPERTIES OF CONCRETE MIXES AND CONCRETES

\begin{tabular}{|c|c|c|c|c|}
\hline Cement type & $\begin{array}{c}\text { Modifier content, } \\
\%\end{array}$ & W/C & $\begin{array}{c}\text { Con } \\
\mathbf{e} \\
\text { slum } \\
\mathbf{p ,} \\
\mathbf{c m}\end{array}$ & $\begin{array}{c}\text { Compressive } \\
\text { strength limit, } \\
\text { MPa (28 days) }\end{array}$ \\
\hline PTs-500-D0 & - & 0.45 & 3 & 41.0 \\
\hline LWRB-50 & 0.45 & 0.33 & 3 & 60.2 \\
\hline
\end{tabular}

\begin{tabular}{|c|c|c|c|c|}
\hline & 0.45 & 0.45 & 20 & 45.1 \\
\hline \multirow{2}{*}{ PTs-500-D0 } & 0.40 & 0.33 & 3 & 51.0 \\
\cline { 2 - 5 } & 0.40 & 0.45 & 20 & 30.1 \\
\hline
\end{tabular}

A $25-30 \%$ decrease of water requirement is possible in the modified concrete mixes compared with the non-modified composition. Increasing the content of the modifier, introduced both during grinding and with gauging water, can lead to a bigger reduction in water requirement. However, the criterion for selecting the optimal conditions for obtaining the LWRB was the minimum water requirement value within the range of $0.33 \ldots 0.35$ during concrete mix preparation, because further increase of the water-cement ratio can decrease the concretes' longevity [9].

When using LWRB-based mortar to produce articles without formwork using additive technologies, it is important to study the influence of the modifier on the plastic strength of the cement paste and the setting time. Fig. 1 shows the dependencies of the plastic strength of mortar mixes on time at the constant water-cement ratio with the introduction of the resorcinol-furfural modifier.

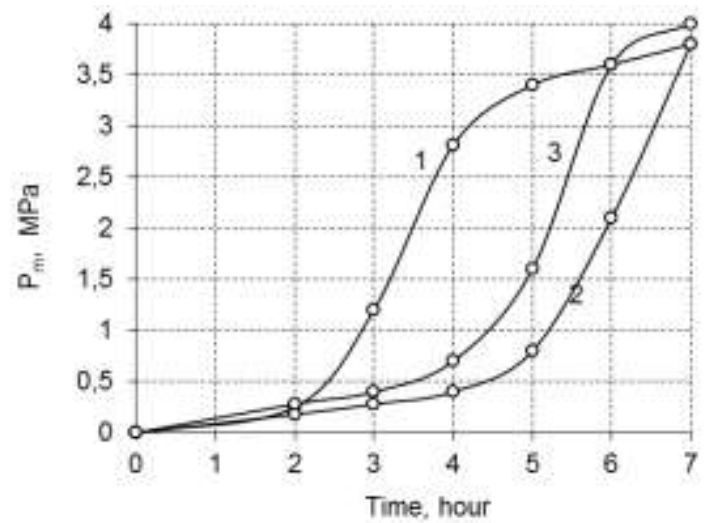

Fig. 1. Influence of the modifier on the plastic strength of cement paste when W/C = const: 1 - no additive; 2 - PTs-500-D0; 3 - LWRB-50

During the first 6-7 hours, the modified mixes show a certain increase of the strength development start time both when using PTs-500-D0 and LWRB-50. This is related to the increase of the hydrophilicity of the binder's modified surface due to adsorption of oligomer molecules and increase of the contact surface caused by peptization of aggregates. Then, the curing of modified cements intensifies compared with the reference sample.

The kinetics of strength development in mixes with equal workability based on LWRB-50 and without additives is shown in Table III.

As can be seen in the presented data, initial retardation of curing is not characteristic for the LWRBs with reduced gauging water content. At the same time, LWRB-based concretes display a more intensive strength development during 1-2 days of curing compared to the reference sample. 
TABLE III. DEPENDENCE OF STRENGTH OF LWRB-50 BASED CONCRETES ON CURING TIME.

\begin{tabular}{|c|c|c|c|c|c|c|c|c|}
\hline \multirow{3}{*}{ 离 } & \multirow{3}{*}{$\mathbf{W} / \mathbf{C}$} & \multirow{3}{*}{$\begin{array}{c}\text { Con } \\
\text { e } \\
\text { slum } \\
\text { p, } \\
\text { cm }\end{array}$} & \multicolumn{6}{|c|}{ Maximum strength, $\mathrm{MPa}$} \\
\hline & & & \multicolumn{3}{|c|}{ Compression } & \multicolumn{3}{|c|}{ Bending } \\
\hline & & & 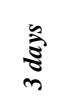 & 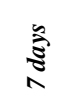 & 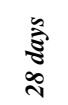 & 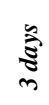 & స్ & 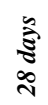 \\
\hline - & 0.45 & 3.0 & 18.5 & 25.3 & 39.0 & 1.9 & 3.0 & 5.5 \\
\hline 0.45 & 0.33 & 3.0 & 31.1 & 41.6 & 60.2 & 2.2 & 4.1 & 7.5 \\
\hline
\end{tabular}

The increased early strength development of such concretes can be used to design innovative mixes for $3 \mathrm{D}$ printing.

Studies of the microstructure of the LWRB rock showed (Fig. 2) a denser microcrystalline structure without largegrained formations or visible defects.

a)

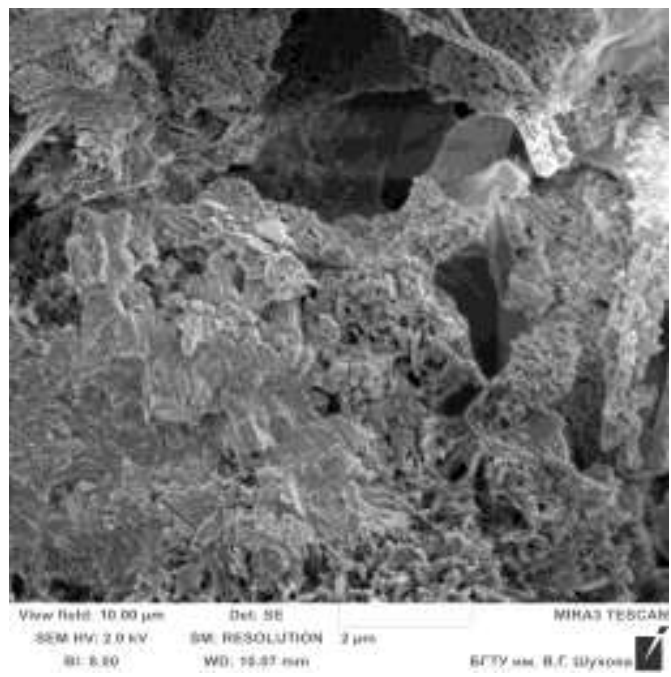

b)

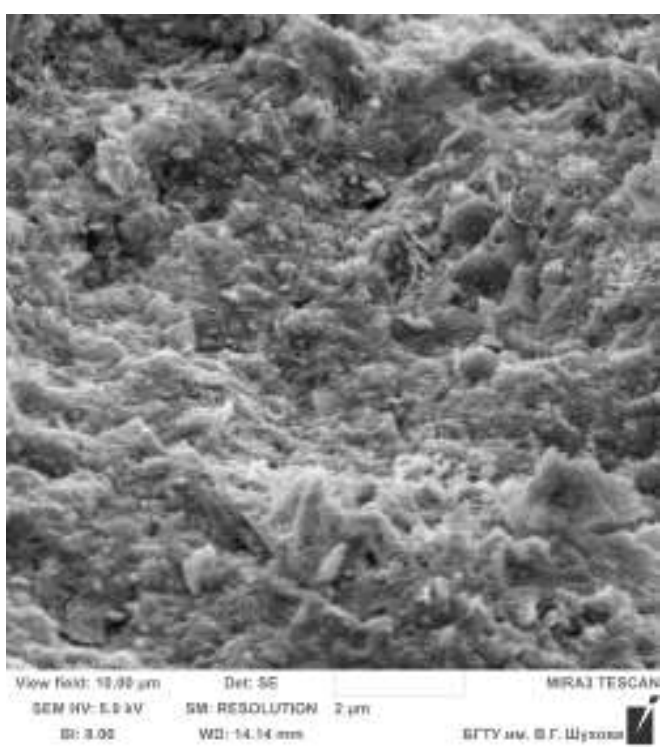

This can be explained by the peptizing effect of the modifier and the more microcrystalline structure of the concrete. Besides, this concrete has a higher strength than the reference samples. This way, strength development of more than $20 \mathrm{MPa}$ is observed in LWRB-based concretes compared with the unmodified reference sample.

\section{Identification of fungal resistance and fungicidity of samples}

The goal of further work was to identify the antifungal properties of the resorcinol-furfural modifier and the biocorrosion resistance of LWRB-based fine-aggregate concretes.

When the environment contains the necessary nutrients, mold fungi can actively colonize the samples that can not suppress or curb the growth of the microbiocenosis.

Research has shown that the resistance to the effect of fungi is sufficiently high in the analyzed modified samples. Being typical heterotrophs, Aspergillus niger and Penicillium do not use concretes with resorcinol-furfural oligomers as a source of nutrition for their development and activity. All tested LWRB-based samples displayed fungal resistance and were bio-corrosion resistant.

Visual observations of the fungal resistance experiment have shown that the samples on the basis of LWRBs with a resorcinol-furfural modifier do not become overgrown with fungal mycelium. Because of the adsorption of the modifier's oligomer molecules on mineral particles, the process of interaction with acids, which are the by-products of fungal activity, is impeded. The 6-point scale assessment (sample/medium) for the reference sample and the test sample is shown in Table IV.

TABLE IV. IDENTIFICATION OF FUNGAL RESISTANCE AND FUNGICIDITY OF THE SAMPLES

\begin{tabular}{|c|c|c|c|}
\hline $\begin{array}{c}\text { Additive } \\
\text { (type) }\end{array}$ & $\begin{array}{c}\text { Q-ty, } \\
\%\end{array}$ & W/C & $\begin{array}{c}\text { 6-point scale } \\
\text { assessment } \\
\text { (sample/medium), points }\end{array}$ \\
\hline Reference & 0 & 0.45 & $2 / 3$ \\
\hline $\begin{array}{c}\text { Resorcinol- } \\
\text { furfural modifier }\end{array}$ & 0.45 & 0.33 & $0 / 0-1$ (unconnected hyphae) \\
\hline
\end{tabular}

An important indicator of the concretes' bio-resistance is the change in the $\mathrm{pH}$ of the aqueous extract from the concretes with the course of time, because most of the fungi cause reduction in $\mathrm{pH}$ when reproducing. During their life, they discharge bio-corrosive products that also lead to decrease in $\mathrm{pH}$ value. Measurements of the $\mathrm{pH}$ values in the aqueous extract from concretes infected by fungi have shown that the introduction of the modifier leads to an insignificant increase in $\mathrm{pH}$ compared with the reference sample (Fig. 3).

Fig. 2. Microstructure of a cement rock (a) and a modified LWRB rock (b) 


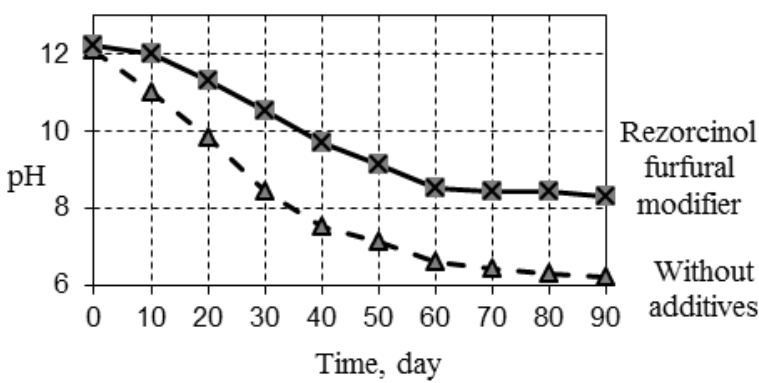

Fig. 3. Dependence of change in the $\mathrm{pH}$ of the aqueous extract from concretes with the course of time.

Change in strength of the cement samples infected with spores of mold fungi over time is shown in Fig. 4.

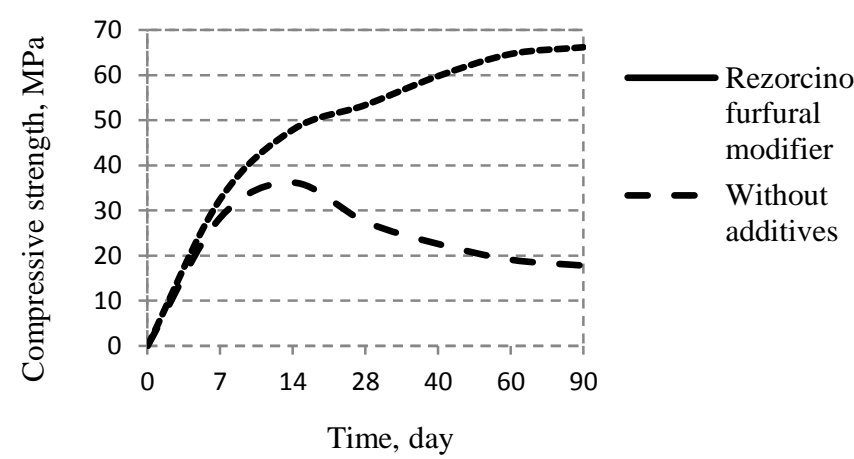

Fig. 4. Change in strength of cement samples over time (samples were infected with mold fungi spores) at constant W/C value

Samples with the additive demonstrate stable strength development over time. A comparative analysis of the strength of reference and modified samples against similar samples obtained from equally workable mixes and infected by fungi is shown in Table V.

TABLE V. INFLUENCE OF INFECTION ON LWRB-BASED SAMPLE STRENGTH

\begin{tabular}{|c|c|c|c|c|}
\hline $\begin{array}{c}\text { Additive } \\
\text { (type) }\end{array}$ & $\begin{array}{c}\text { Q-ty, } \\
\%\end{array}$ & W/C & $\begin{array}{c}\text { Uninfected } \\
\text { sample } \\
\text { strength } \\
\text { Rcomp., } \\
\text { MPa }\end{array}$ & $\begin{array}{c}\text { Infected } \\
\text { sample } \\
\text { strength } \\
\text { Rcomp., } \\
\text { MPa }\end{array}$ \\
\hline Reference & 0 & 0.45 & 59.3 & 59.0 \\
\hline $\begin{array}{c}\text { Resorcinol- } \\
\text { furfural modifier }\end{array}$ & 0.45 & 0.33 & 74.5 & 79.3 \\
\hline
\end{tabular}

The data obtained from this experiment allowed one to make a conclusion that the synthesized additive based on resorcinol-furfural rezols possess antifungal properties and allow one to obtain concretes with increased strength properties.
This way, the use of the resorcinol-furfural modifier in producing LWRBs allows one to eliminate the effect of mold fungi on concretes. The obtained biocidal modifier can be used to improve technological properties and protection of building materials. It meets the requirements to toxicology monitoring and hygiene, its performance is on par with the existing concrete additives and exceeds many of them.

\section{CONCLUSION}

The modifier based on resorcinol-furfural resols possesses a number of useful properties: plasticizing and water-reducing effects, antifungal properties; it increases strength properties and, consequently, can be classified as a polyfunctional modifier for concrete.

The results of this research show that the polyfunctional resorcinol-furfural modifier can be used to produce innovative high-strength materials for use in additive manufacturing [1218] and further use of the produced articles in biologically active environments.

\section{FINDINGS}

Studies have shown that use of the modifier based on resol-type resorcinol-furfural oligomers allows one to obtain LWRBs with high specific surface area and compressive strength. A $25-30 \%$ decrease of water requirement is possible in LWRB-based mixes compared with the non-modified composition.

LWRB-based concretes display a more intensive strength development during 1-2 days of curing compared to the reference sample. During this process, a denser microcrystalline structure with no large-grained formations or visible defects is formed. Rated strength development of more than $20 \mathrm{MPa}$ is observed in LWRB-based concretes compared with the unmodified reference sample.

The increased early strength development of the concretes of this composition can be used to design innovative mixes for $3 \mathrm{D}$ printing.

As was demonstrated by the performed studies, the introduction of the optimal quantity of the polyfunctional modifier in the composition of a binder completely suppresses the growth of mold fungi, that are identified on the surfaces of similar but unprotected concrete samples.

Strength properties of the concrete with the modifier in question are significantly increased due to the decrease of the $\mathrm{W} / \mathrm{C}$ ratio, the reduction of microfractures within the concrete, higher density of its structure, and absence of bio-corrosion.

\section{Acknowledgment}

The article was prepared within a development program of the Base University on the basis of BSTU named after V. G. 
Shoukhov, using the equipment of High Technology Center at BSTU named after V.G. Shoukhov.

\section{References}

[1] I.V. Shapovalov, L. Yu. Ogrel, M.M. Kosukhin, V.I. Pavlenko, Yu.V. Popova, N.A. Shapovalov, A.A. Sliusar, "Fungitsidnyi modifikator mineralnykh stroitelnykh kompozitsiy" ["Fungicide modifier for mineral building compositions"], Patent 2235695 RF. Published 07.10.02, pp. 6.

[2] I.V. Shapovalov, L.Yu. Ogrel, M.M. Kosukhin, V.I. Pavlenko, Yu.V. Popova, N.A. Shapovalov, and A.A. Sliusar, "Fungitsidnyi modifikator mineralnykh stroitelnykh kompozitsiy" ["Fungicide modifier for mineral building compositions"], Ekologicheskie sistemy i pribory [Ecological systems and devices], 4, pp. 50-51, 2006.

[3] Sh.T. Babaev, "Vysokoprochnye betony na osnove viazhushchikh nizkoi vodopotrebnosti" ["High-performance concretes based on low water requirement binders"], Promyshlennost stroitelnykh materialov. Seriya 3. Promyshlennost sbornogo zhelezobetona VNIIESM [Building materials industry. Series 3. VNIIESM precast reinforced concrete industry], 4, pp.16-30, 1990.

[4] V.I. Kalashnikov, A.A. Borisov, L.G. Poliakov et al, "Sovremennye predstavleniia ob ispolzovanii tonkomolotykh tsementov i VNV v betonakh" ["Contemporary views on the use of fine-ground cements and LWRBs in concretes"], Stroitelnye materialy [Building materials], No.7, pp. 12-13, 2000

[5] Sh.T. Babaev, "Vysokoprochnye betony na osnove viazhushchikh novogo pokoleniia" ["High-performance concretes based on the newgeneration binders"], Promyshlennost sbornogo zhelezobetona. Seriia 3 /VNIIESM [Precast reinforced concrete industry, Series 3/VNIIESM], Moscow: 1990, pp.16-30.

[6] V.E. Iudovich, A.M. Dmitriev, S.A. Zubekhin et al, "Tsementy nizko vodopotrebnosti - viazhushchie novogo pokoleniia" ["Low water requirement cements - new-generation binders"], Tsement i ego primenenie [Cement ind its use], 4, pp.15-18, 1998.

[7] A.A. Sliusar, V.A. Poluektova, V.D. Mukhacheva, "Beton na osnove viazhushchego nizkoi vodopotrebnosti i modifikatora SB-FF" ["Concrete based on low water requirement binder and SB-FF modifier"], Stroitelnye materialy [Building materials], 9, pp. 65-66, 2009.

[8] N.A. Shapovalov, A.A. Sliusar, M.M. Kosukhin, O.V. Mukhachev, "Superplastifikator SB-5 kak modifikator pri poluchenii VNV i betonov na ikh osnove" ["SB-5 superplasticizer as a modifier in obtaining LWRBs and concretes on their basis"], Beton i zhelezobeton [Concrete and reinforced concrete], 6, pp. 2-4, 2001

[9] V.V. Babkov, A.F. Polak, P.G. Komokhov, "Aspekty dolgovechnost tsementnogo kamnia" ["Aspects of longevity of cement rock"], Tsement [Concrete], 3, pp. 14-16, 1988.

[10] GOST 24211-2008. Dobavki dlia betonov i stroitelnykh rastvorov. Obshchie tekhnicheskie usloviia [Additives for concretes and construction mixes. General specifications]. Moscow: Standartinform, 2010, $12 \mathrm{pp}$

[11] V.A.Poluektova, N.A. Shapovalov and A.I. Gorodov, "Modifiers On The Base Of Oxyphenol Chemical Production Waste For The Industrial Mineral Suspensions," International journal of applied engineering research, vol. 10(21), pp. 42654-42657, 2015

[12] K. Kazmirchuk and V. Dovbysh, "Additivnye tekhnologii v rossiiskoi promyshlennosti" ["Additive technologies in Russian industry"], 2012 (http://konstruktor.net/podrobnee-det/additivnye-texnologii-v-rossijskojpromyshlennosti.html).

[13] M.A. Zlenko, A.A.Popovich, I.N. Mutylina, "Additivnye tekhnologii v mashinostroenii: Uchebn. Posobie" ["Additive technologies in machine building: a textbook"], Saint Petersburg: SPbGU, 2013, p. 221

[14] A. Maslov, "Stroitelnaia 3D pechat. Smesi. Prakticheskie rekomendatsii" ["3D printing in building. Mixes. Practical guidelines"], 2016 (http://specavia.pro/articls/Stroitelnaja-3D-pechat-Smesi-Prakticheskierekomendacii/)

[15] Date Views market study reports 01.02 .2016 http://www.marketsandmarkets.com/.

[16] N. Vatin, L. Chumadova, I. Goncharov, V. Zykova, A. Karpenya, A Kim, E. Finashenkov, "3D printing in construction," Construction of Unique Buildings and Structures, 1(52), pp. 27-46, 2017

[17] Nanotekhnologii kak kliuchevoi faktor novogo tekhnologicheskogo uklada $\mathrm{v}$ ekonomike [Nanotechnologies as a key factor of the new technological setting in economy] / Eds. RAN Academician S.Yu. Glazev and Professor V.V. Kharitonov, Moscow: "Trovant", 2009, p. 304

[18] A.N. Ponamorev, "Vysokokachestvennye betony. Analiz vozmozhnostei i praktika ispolzovaniia metodov nanotekhnologii" ["Hight-quality concretes. Study of opportunities and practices of using nanotechnology methods"], Inzhenerno-stroitelnyi zhurnal [Journal of engineering and construction], 6, 2009, pp.25-33 